\title{
The Tlemcen (NW-Algeria): Urban Colonial Heritage as a Tourist Attraction
}

\author{
Nabil Kari ${ }^{1}$, Joan Curos Vila ${ }^{2, *}$, Cherif Bemmoussa Wissem ${ }^{3}$ \\ ${ }^{1}$ Department of Architecture, Faculty of Civil Engineering and Architecture, Hassiba Benbouali University of Chlef, N19, \\ Ouled Fares Chlef 02180, Algeria \\ ${ }^{2}$ Department of architectural design, Polytechnic University of Catalonia, Av. Diagonal, 649 (08028 BARCELONA), Spain \\ ${ }^{3}$ Department of Architecture, Faculty of Architecture and Civil Engineering, University of Science and Technology of Oran - \\ Mohamed Boudiaf-, El Mnaouar BP 1505, Bir El Djir 31000, Oran, Algeria
}

Receive April 14, 2021; Revised August 24, 2021; Accepted September 21, 2021

\section{Cite This Paper in the following Citation Styles}

(a): [1] Nabil Kari, Joan Curos Vila, Cherif Bemmoussa Wissem, "The Tlemcen (NW-Algeria): Urban Colonial Heritage as a Tourist Attraction," Civil Engineering and Architecture, Vol. 9, No. 6, pp. 1996-2010, 2021. DOI: 10.13189/cea.2021.090628.

(b): Nabil Kari, Joan Curos Vila, Cherif Bemmoussa Wissem (2021). The Tlemcen (NW-Algeria): Urban Colonial Heritage as a Tourist Attraction. Civil Engineering and Architecture, 9(6), 1996-2010. DOI: 10.13189/cea.2021.090628.

Copyright $\odot 2021$ by authors, all rights reserved. Authors agree that this article remains permanently open access under the terms of the Creative Commons Attribution License 4.0 International License

\begin{abstract}
This paper discusses the importance of urban colonial heritage aspects identification in the promotion of tourism in the case of the old city of Tlemcen. The latter was one of the Algerian traditional Arab-Muslim cities occupied during the 19th century by the French colonial armies. According to their "supposedly" civilizing project, the French Génie Militaire has remodeled the city's traditional fabric to modernize and transform the colonial territories. So, amongst other cases of historic Algerian towns, and after the installation of the European community, the old city of Tlemcen began gradually to forge a new identity, which was resulted from profound transformations that affected its socio-spatial structure. The city of Tlemcen experienced, during this period, the introduction of new urban principles. The French colonial authority aimed to transform the city of Tlemcen to meet the 19th European community's requirements. The European cities' architecture and urbanism were, therefore, seen as models that symbolize modernity. In a relatively short period, the Tlemcen ancient city was changed from a city with old Arab-Muslim cities' urbanism to a town with modern European urbanism. The impressive urban dynamic was engaged at that time to make the city more modern and less introverted. Today, apart from the Tlemcen's Medina remains, we cannot ignore the richness of the built colonial heritage in the Tlemcen old city center and that it constitutes a valuable tourism resource. Thus, the aspects of these built heritage attractions need to be
\end{abstract}

identified for the community to be preserved and valorized to promote tourism in this historical place. The paper is thus aiming at identifying urban colonial heritage and understanding how crucial it is to take them into account in the process of tourism promotion in the case of Tlemcen's old city center. Based on documentary research and a qualitative approach achieved through walking inquiries, informal discussions with local community representatives, visitors, professionals and institutional actors, the reconnaissance work has brought out the main elements of the built colonial heritage and the urban planning characterizing the long period of colonial presence in Tlemcen, which are considered to have aesthetical and testimonial values and can therefore be seen as an asset for the Tlemcen city tourism enhancement.

Keywords Urban Colonial Heritage, Tlemcen City Center, French Colonization, Heritage Identification, Tourism Development, Historic Cities, Urban Design, Architecture, Colonial Urbanism

\section{Introduction}

Tlemcen is one of the historic cities located in the extreme west of Algeria (Figure 1). Throughout the ages, the territory of this city hosted different civilizations, each 
one of these civilizations left urban or architectural marks testifying to their presence or passing. After being under the reign of Idrissids, Almoravids, Almohads, Zayyanids, and Ottomans, Tlemcen knew the arrival of a new
European population with a different culture, starting from 1830, the date in which Algeria became under the control of the French colonial authority.

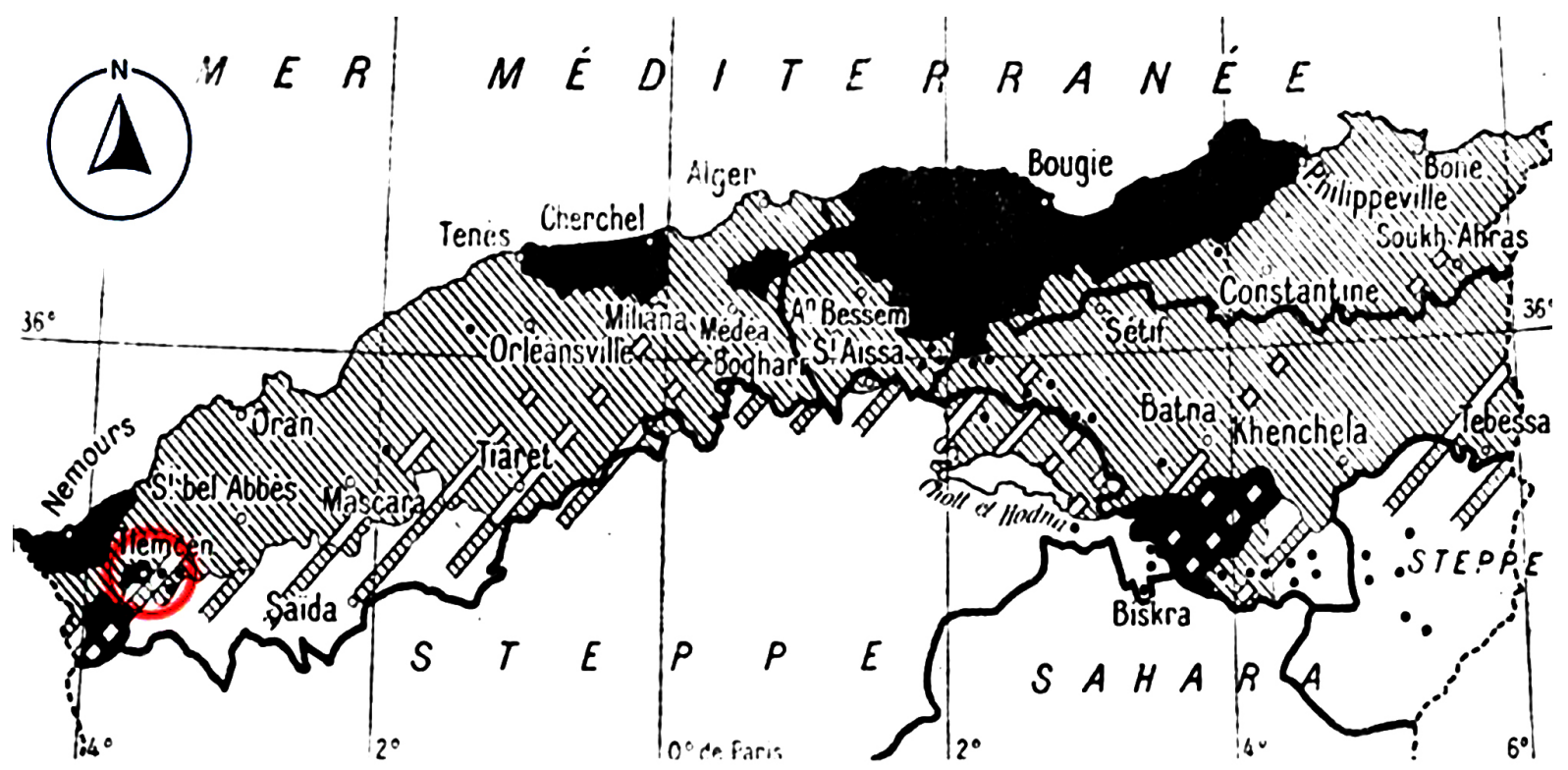

Figure 1. In black, on the left side of the figure, the Tlemcen Medina is a region on which are present oldest settlements in the north of Algeria, according to M.M. Larnaude. Source: M.M. Larnaude. (1944) [1]

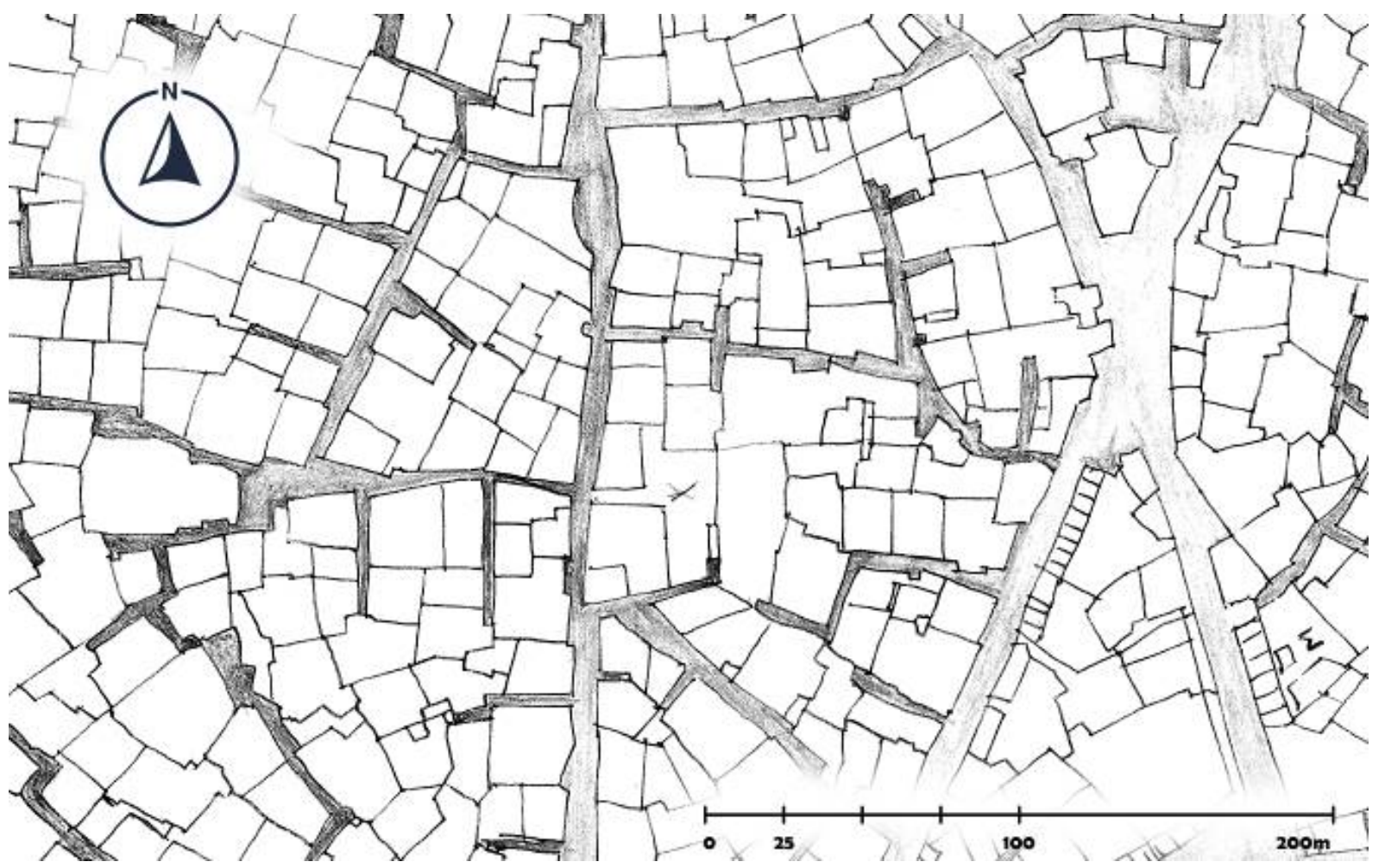

Figure 2. The traditional urban pattern of the old Medina of Tlemcen. Source: historical archives of the French war department of chateau de Vincennes 
This city, with its traditional aspect and uniform architectural character that inspired a true socio-cultural homogeneity and also with the shapes of its curved and blind alleys, very high density, knew the introduction, from 1842, of a new exogenous urban structure which resulted from a series of radical and profound transformations that have affected the Medina spatial and morphological old structure (Figure 2 and 3).

The engineers made a detailed analysis of the Génie Militaire in which the buildings of the Medina were considered not to be solid and without any aesthetic value. They have also seen that the public spaces of the Medina were not suitable for the military needs and the commercial future intends. For those needs, the military engineers have worked to widen the tight alleys and create parade grounds [2].

These sixty years old transformations have changed the original face of the old Medina. It is nowadays seen as a dual city composed of two different and juxtaposed kinds of urbanism. In the Medina of Tlemcen since 1902, this duality is essentially the result of an approach led in Morocco by Marshal Lyautey [3], who wanted to keep apparent differences between native neighborhoods and the new European ones [4].

However, this architectural and urban contrast is now a real tourist asset that contributes enormously to the cultural and economic development of the city, which can be achieved through the attractiveness of the architectural and urban diversity of the Tlemcen two main historical periods.

In this article, we will try to identify the main urban and architectural elements of the city of Tlemcen during the French colonial occupation period that symbolized this era of modernity against the modesty of the pre-colonial city.

\section{Methodology}

To correctly identify the Tlemcen old city urban heritage aspects created during the French occupation period, the methodology adopted in this research is based on a documentation study. Research and readings on architecture and urbanism produced during this period in Algeria and particularly in the Tlemcen old city were done to understand the architectural and urbanism characteristics of the French urban fabric. Recent and ancient Documents were gathered from various sources; The important ones are brought from the Vincennes (France) historical archives center and old postcards (African photo editions).

The research's methodology is not based only on documentary research but also on qualitative data collection methods. It consisted of walking inquiries that ensure an overview of the studied area and give the possibility to gain more understanding about the information gotten by the documentary research about the French colonial urbanism aspects in the old Tlemcen city center.

Also, for the identification of urban colonial heritage aspects and their importance in tourism development in the old city center of Tlemcen, the work involved informal discussions with employees of concerned departments, architects, graduate and Ph.D. students, tourists, and residents. The informal talks were carried out with 36 people. The first part of the discussion was concerned with obtaining informants' personal information such as age, place of residence, and education level. The second part aimed to identify the informant's perceptions and awareness about the Tlemcen city center urban colonial heritage, its aspects identification, and the importance of this step in enhancing tourism.

In the case of employees (table 2) and architects, the discussions took place in their offices and have lasted about 55 minutes. In the case of the other profiles, the discussions' time was reduced to an average of 40 minutes to minimize disturbance and fatigue for both tourists and residents.

\section{The Importance of Informal Talks}

Informal discussion with employees of the concerned department, architects, graduate and Ph.D. students, tourists, and ancient was the building block of our research methodology to get an insight into users' perceptions. This methodological tool was seen as a constitutive element of qualitative data acquirement for a long time. Among other qualitative researchers, Sydney and Beatrice WEBB believe that informal conversations should be considered an important research technique because of their great potential of generating valuable data without framing the participants' responses according to the researcher's conceptualizations; this is one of the weaknesses of interviews or questionnaire.

Within the framework of this research topic, Informal talks as a methodological tool aim to gain a deep and clear understanding of colonial heritage and its features in its particular cultural context. They help to explore appropriately how people conceptualize colonial heritage.

In most cases, our research's informal talks take place in the Tlemcen city center colonial part. The authors engage the informants in a conversation about the value of the colonial urban heritage and its characteristics to understand what's important for them concerning this kind of heritage. Informal talks allow us to get more insight into the value of colonial-built heritage and the importance of its identification to be conserved and valorized as a tourist attraction.

Once conversations are made, notes were derived from the content of the informal talk. The mains areas of discussion that the informal talks have highlighted are presented in the table below: 
Table 1. Informal talk's content

\begin{tabular}{|c|c|}
\hline Informants’ Profiles & Areas of discussions \\
\hline \multirow{4}{*}{$\begin{array}{l}\text { Different department } \\
\text { employees, architects, } \\
\text { and students. }\end{array}$} & If there any any specifications regarding urban colonial heritage in the Tlemcen province tourism strategy lines. \\
\hline & $\begin{array}{l}\text { Informant's point of views about urban colonial heritage in the city of Tlemcen and its potential contribution to } \\
\text { tourism development. }\end{array}$ \\
\hline & Favorite touristic paths and places in the Tlemcen city center for visitor. \\
\hline & The need for the urban colonial heritage aspects identification to promote Tlemcen old city center tourism. \\
\hline \multirow{6}{*}{ Tourists } & To what extent the tourism experience lived in the old city center of Tlemcen was interesting. \\
\hline & The most liked aspects in the old city center of Tlemcen? \\
\hline & If there a uniqueness and amazement value in Tlemcen city center and to what it is related. \\
\hline & If the informant can cite some visited places. \\
\hline & A description of the Tlemcen city center's visited part (colonial side) and its most attractive aspects? \\
\hline & If there a need for urban colonial heritage aspects identification to promote Tlemcen old city center tourism? \\
\hline \multirow{3}{*}{ Residents } & A description of the informant's childhood and its most attractive aspects? \\
\hline & What do you like the most in the old city center of Tlemcen? \\
\hline & If there a need for urban colonial heritage aspects identification to promote Tlemcen old city center tourism? \\
\hline
\end{tabular}

However, due to time constraints, the use of a non-probability purposive sampling technique was preferred. Our research objective is to identify the importance of the colonial heritage features as a tourist attraction. Thus, a good section of 36 informants, whose availability and attitude are compatible with our research, were approached.

Table 2. Informal talk's profiles (36)

\begin{tabular}{|c|c|c|c|c|}
\hline $\mathrm{N}$ & $\begin{aligned} \text { Profile }\end{aligned}$ & Age & Residence & Time \\
\hline & Employee of department of culture (Tlemcen) & 42 & Tlemcen & 52 \\
\hline 02 & Architect, employee of department of tourism (Tlemcen). & 53 & Tlemcen & 55 \\
\hline 03 & Representant of the Tlemcen communal people's assembly & 61 & Tlemcen & 53 \\
\hline 04 & Representant of the Tlemcen provincial people's assembly & 59 & Tlemcen & 56 \\
\hline 05 & Employee of the province (Wilaya) of Tlemcen & 53 & Tlemcen & 60 \\
\hline 06 & $\begin{array}{l}\text { Architect, employee of Urbanism, Architecture and construction } \\
\text { department (Tlemcen) }\end{array}$ & 47 & Tlemcen & 50 \\
\hline 07 & Architect (architectural consulting and design office) & 44 & Tlemcen & 57 \\
\hline 08 & Architect (architectural consulting office) & 35 & Tlemcen & 50 \\
\hline 09 & Graduate Student (architecture and heritage preservation) & 25 & Tlemcen & 56 \\
\hline 10 & Graduate Student (architecture and heritage preservation) & 23 & Tlemcen & 53 \\
\hline 11 & Graduate Student (urbanism) & 24 & Tlemcen & 56 \\
\hline 12 & Graduate Student (urbanism) & 22 & Tlemcen & 58 \\
\hline 13 & Graduate Student (urbanism) & 23 & Tlemcen & 53 \\
\hline 14 & Phd student (urbanism and heritage preservation) & 32 & Tlemcen & 52 \\
\hline 15 & Phd student (urban heritage preservation) & 34 & Tlemcen & 58 \\
\hline 16 & Resident (retired) & 64 & Tlemcen & 41 \\
\hline 17 & Resident (retired) & 67 & Tlemcen & 40 \\
\hline 18 & Resident (housewife) & 56 & Tlemcen & 42 \\
\hline 19 & Resident (merchant) & 47 & Tlemcen & 47 \\
\hline 20 & Resident (merchant) & 52 & Tlemcen & 45 \\
\hline 21 & Resident (merchant) & 48 & Tlemcen & 43 \\
\hline 22 & Tourist (student) & 24 & Oran & 44 \\
\hline 23 & Tourist (retired) & 63 & Tunisia & 42 \\
\hline 24 & Tourist (housewife) & 56 & Bechar & 43 \\
\hline 25 & Tourist (employee) & 42 & Algiers & 40 \\
\hline 26 & Tourist & 54 & France & 46 \\
\hline 27 & Tourist & 38 & Setif & 43 \\
\hline 28 & Tourist (retired) & 66 & Saida & 40 \\
\hline 29 & Tourist (employee) & 43 & Ain tmouchnt & 42 \\
\hline 30 & Tourist & 42 & Constantine & 41 \\
\hline 31 & Tourist (student) & 24 & Media & 48 \\
\hline 32 & Tourist (Merchant) & 35 & Msila & 42 \\
\hline 33 & Tourist (retired) & 68 & Chlef & 41 \\
\hline 34 & Tourist (housewife) & 57 & Oran & 40 \\
\hline 35 & Tourist (employee) & 43 & Algiers & 43 \\
\hline 36 & Tourist (archeologist) & 47 & France & 48 \\
\hline
\end{tabular}




\section{Literature Review}

\section{The Tlemcen City Urbanism: the Civilizations Marker}

The urbanism of the Tlemcen Medina was shaped by several marks left by civilizations that have developed on their territory. According to literature, it is reported that the history of this city began in the third century with the Roman occupation [5]. During this period, a military garrison was established in the northeast of the present-day Tlemcen [6] because of the strategic position and the topography of the occupied site that allows the Romans to dominate and control all the surrounding plain [7]. Thus, Pomaria was founded in a sixteen-hectare area [8] known for the abundance of greenery and particularly fruit trees. Over two centuries later, the Pomaria was seized by the Vandals and was destroyed [9].

In the eighth century, the surrounding areas of the present city of Tlemcen hosted Idris 1st, who was the father of Idris 2nd, the founder of Fez who had entered the territory of Tlemcen and occupied the site of the destroyed Pomaria and ordered the construction of the Grand Mosque [9] and the foundation of the city of Agadir on the ruins of the Roman destroyed city [11]. This city had been under the reign of the Idrisids dynasty until the arrival of the Almoravids.

In the 12th century and during the year 1169, the history of Tlemcen knew for the first time the remarkable personality of Yusuf Ibn Tashfin, who built Marrakech in 1060 and brought Fez, Algiers and certain parts of Spain under the control of its dynasty [11]. After taking control of the Idrissids capital Agadir, Ibn Tashfin established a fortress named Tagrart on a high plain overlooking the surrounding areas. The Almoravids and from the year 1069 contributed to developing the city's urbanism by the foundation of the Grand mosque and a palace-fortress named Al qsar al qadim [13].

Between 1143 and 1235, Tlemcen was under the reign of the Almohads that crushed the Almoravids and controlled the entire Maghrib and $\mathrm{Al}$ Andalus for more than a centuryi[11]. During this time, Almohads contributed to the development of the Tlemcen city by constructing solid ramparts protecting and unifying the city, the construction of Palaces and Funduks, and the extension of the Grand Mosque [15].

From 1236, the city was under the reign of the Zayyanids, who established a new authority and contributed to the foundation of a new realm in which Tlemcen became the capital [11] and controlled, between 1236 and 1550, a territory covering approximately all the west of Algeria.

In the beginning, the Zayyanids constructed the Mechouar as a royal residence, two minarets: the first for the Grand mosque and another for the Agadir mosque and, later on, other Mosques and Madrassa [16].

From 1555 the city of Tlemcen was occupied by the
Ottomans who settled in the southwestern of the Medina and founded the Bâb Elhadid District. According to El Amir Abdelkader Aljazairi, the city of Tlemcen was devastated by the Turks; its walls and its fortifications were destroyed. The mosque and Madrassa endowments were ransacked; the student of science was disrupted. They continued to destroy the city until it was handed over to French colonialism in 1830.

The French occupation of Tlemcen began in 1836, under the command of Marshal Clauzel. Some years later, the French military engineers began to draw up street plans and prepare schemes for the new European district projects and were also responsible for their execution and administration [18].

At first, the French army had to house troops in existing buildings and ancient military structures, as was the case of the Mechouar, which was occupied just before the signature of the "Tafna treaty" in 1837. It was only after 1842 that the definitive occupation of the Tlemcen Medina began, and since that, the medieval city of Tlemcen was quickly transformed. The objective of those transformation operations was the creation of a European quarter superposed to the old town [2].

Therefore, the operations were radical and led to the destruction of many houses and important indigenous structures, such as the Madrasa Techfinia and the Qissaria. The modernism that had reached Haussmann's France is thus manifested in Algeria; in line with the Haussmann progressive vision in Paris, the solution of breakthrough roads is imperative in the eyes of the French engineers that ordered the creation of a large number of breakthrough roads as the Rue de France and the Rue de Paris. From 1846, the French authorities endowed the city with the necessary functions to become a Sub-prefecture. a church and a tribunal, among others, were constructed [19].

In 1902, the transformation of Tlemcen was done, with which the alignments project created streets and squares in line with the 19th-century European urbanism.

\section{The Genesis of the Tlemcen Colonial Urban Heritage and Its Design Concepts}

In the 19th century, European cities saw the rise of an ideology developed by senior officials aiming to improve living conditions and solve unhealthy dwellings and other severe problems of the old medieval towns (Figure 3). That was also because of military reasons for why the engineering services advised that the future projected quarters should ensure reasonable military control.

European ideas of modernity were replicated in the case of the Tlemcen Medina renewal project. The French military engineers took the liberty to borrow generously from the ideas of one of their colleagues, Eugène Haussmann, perceived as a model during the late 19th century [18]. 


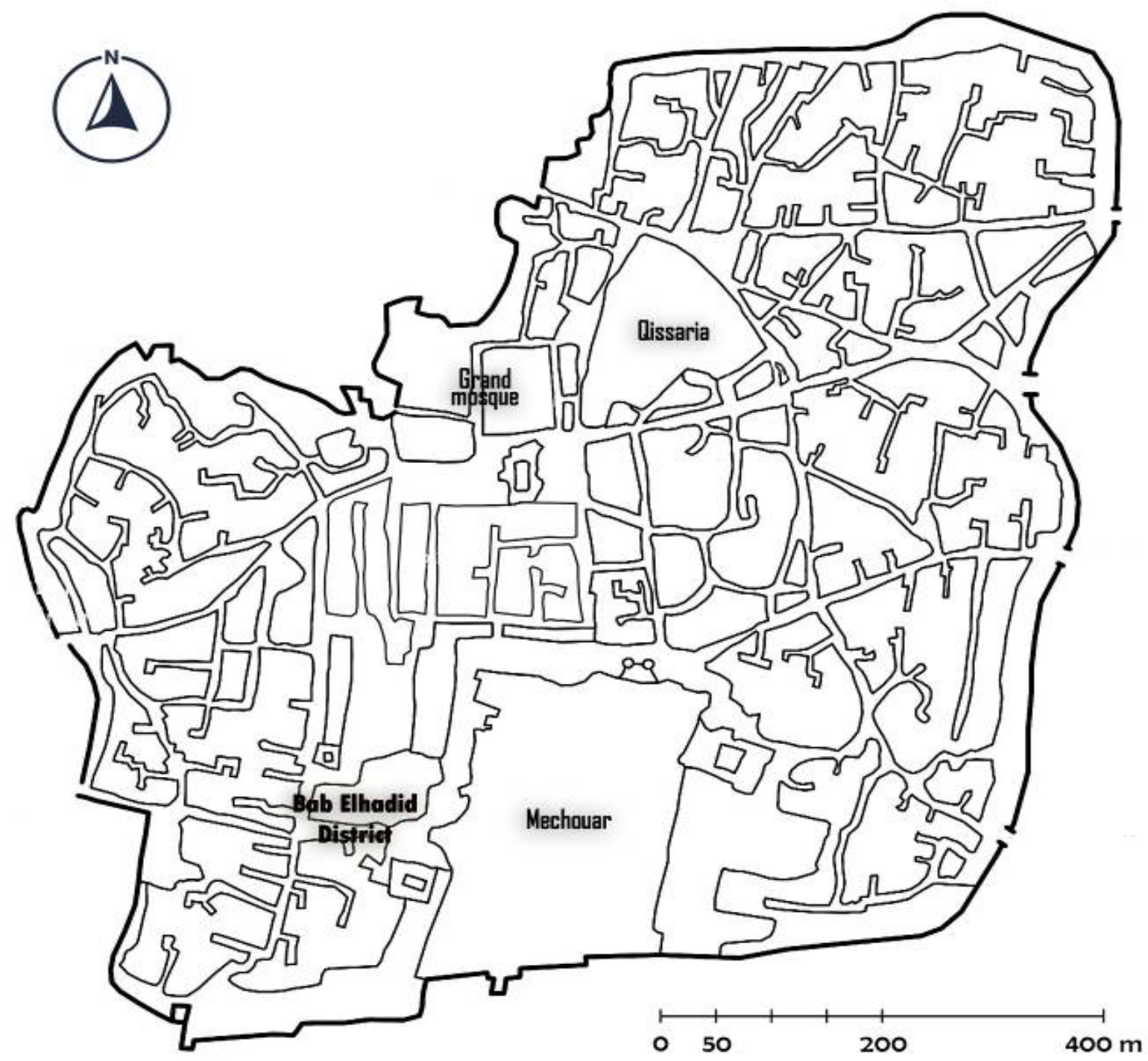

Figure 3. The Tlemcen ancient city plan before the arrival of the French colonial army. Source: Authors 


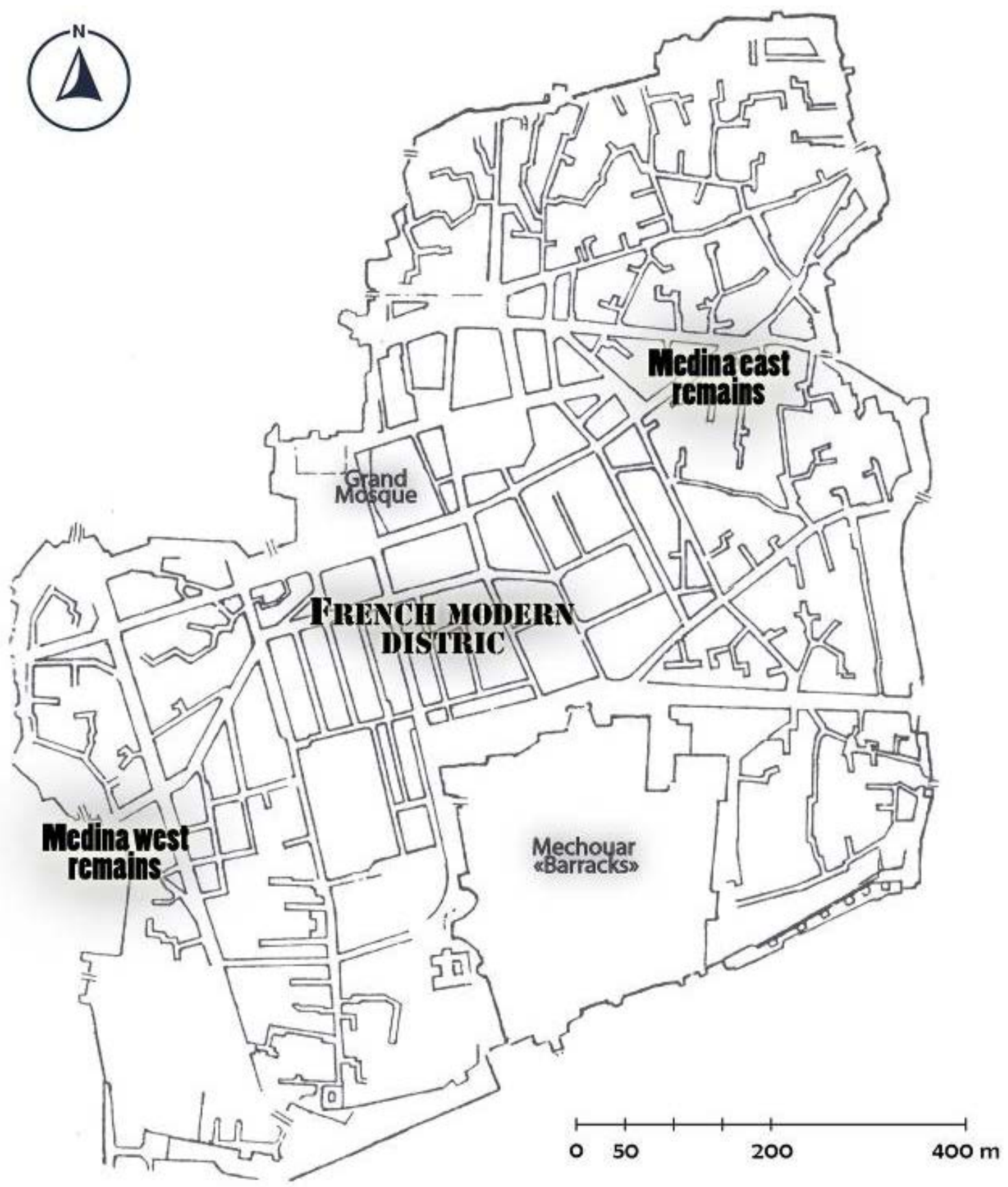

Figure 4. The Tlemcen ancient city plan after the French urban transformations. Source: Authors

In the context of Tlemcen, the engineers of those operations were cutting through the old city in a Haussmannian manner, attempting to regularize its traditional concentric fabric and which was the inevitable counterpart to the demolition of the ancient city narrow streets [19].

\section{Results and Discussions}

According to the adopted methodology based on documentary research, we have concluded how vital were the transformations carried out during the period of the French colonial occupation for the city's economic growth and, potentially, for the recent issue of tourism development. The operations made during this period allowed the introduction of a modern European urbanism over the ancient Medina traditional urbanism (Figure 4), giving rise to one of the rare dual cities in the world.

Through the analysis of the ancient urbanism documents 
of the Tlemcen city center, the walking inquiry, and according to the informal talks' findings, we were able to bring out the main aspects of the urban colonial heritage which need to be taken into account and valorized for a potential tourism enhancement strategy. The latter and according to informal talks' findings, has no specifications regarding the colonial heritage. So, it needs to be comprehensive and take into account all the potential cultural resources in Tlemcen and not only the relatively ancient and valuable monuments located in the Medina's fabric remains.

Beyond economic purposes, the tourism strategy openly affirms the will of the Algerian state to preserve the environment, improve the standards of living, valorize and perpetuate the cultural capitals. Thus, the great part of the informal talks' informants confirmed that: a tourism strategy needs to be built upon the development of cultural and historic colonial quarters of the Tlemcen city center considering their assets and attractiveness.

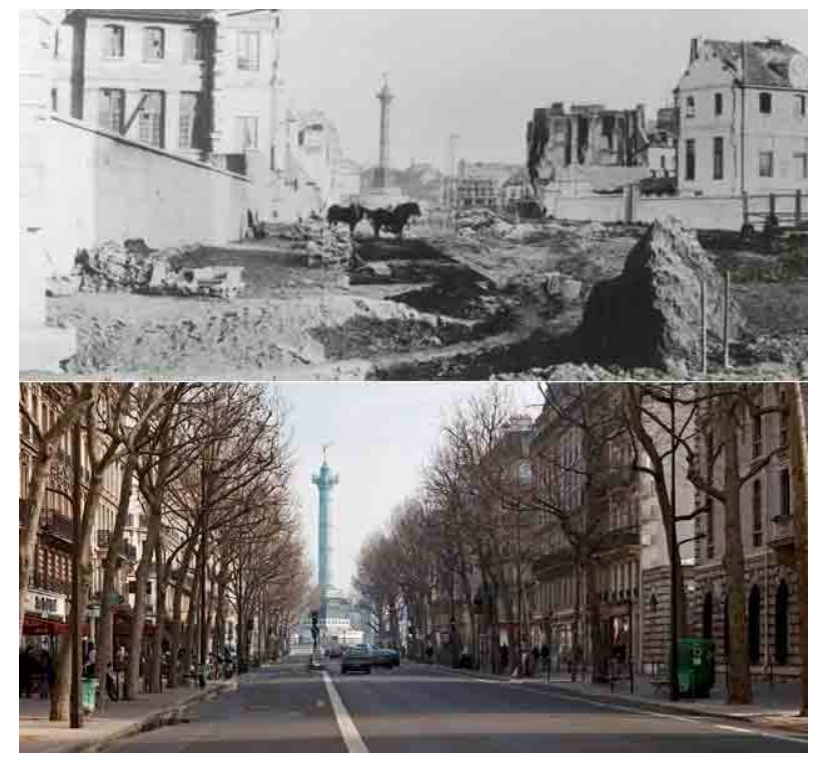

Figure 5. One of the Parisian quarters, after and before the regularization project of Haussmann (Dates: 1853-2008). Source: Patrice de Moncan et Charles Marville [17]

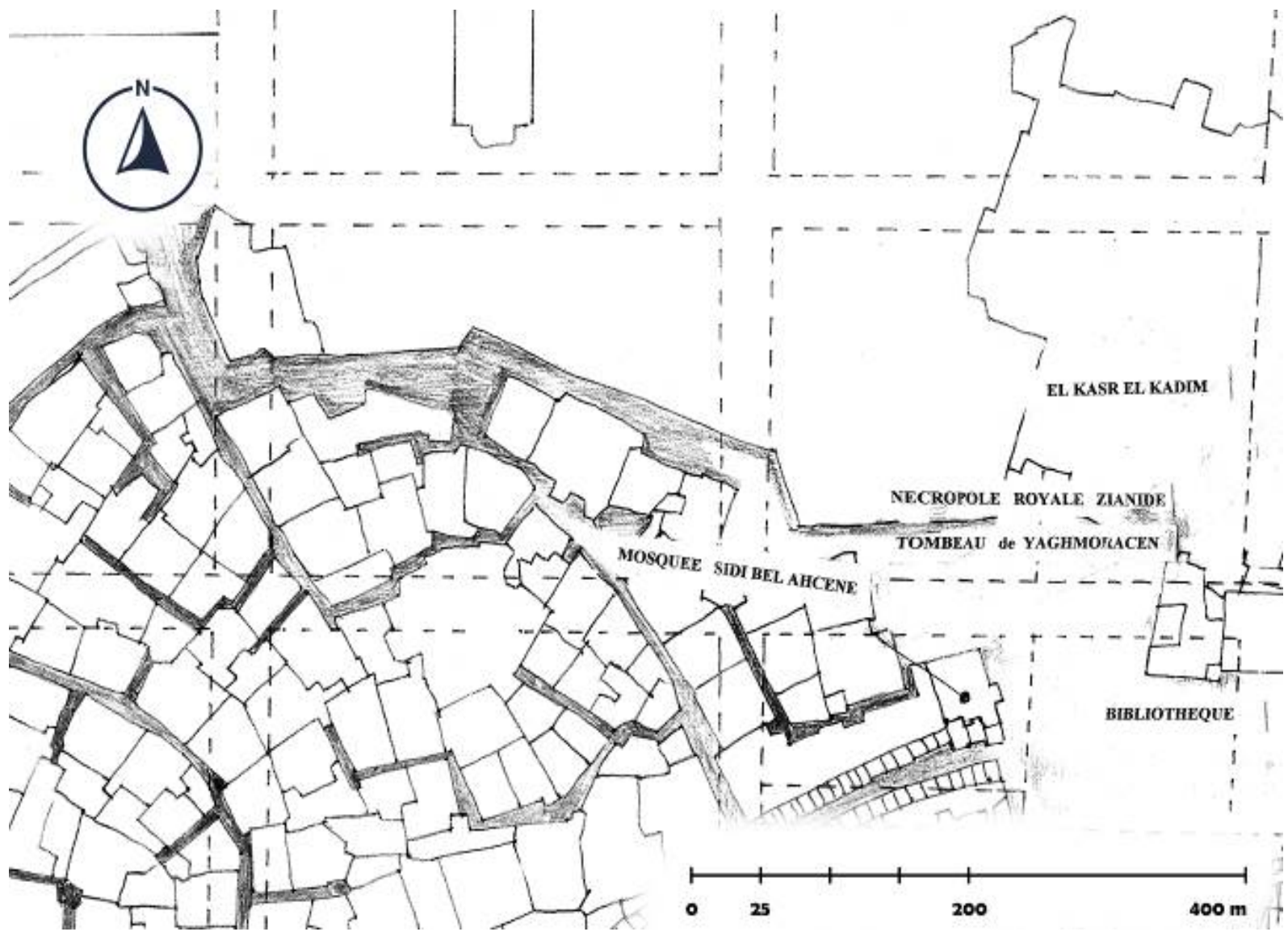

Figure 6. The suggested urban pattern superposed over the oldest quarter in the Medina of Tlemcen (Bab Zir quarter) drawn up by the military engineers. Source: historical archives of the French war department of chateau de Vincennes. 
However, other informants' reactions express the disinterest of public authorities and the indifference of civil society. None of them is passionate about the identification and conservation of urban heritage aspects in the case of Tlemcen city center. For this part of informants, it seems that the colonial part of the city is still strongly associated with colonization that would not have disappeared yet.

Therefore, raising tourism, culture, and other concerned department awareness to enhance urban colonial heritage situation for economic development, social pacification of morals and territorial marketing to counteract the effect of negative thinking about this heritage and the neglect in which the situation in which it was since decades.

Architects, experts in the field, students, and a big part of residents have shown great sensitivity and appreciation vis a vis the issue of colonial heritage. They believe that it is essential for sustainable tourism to identify the urban colonial heritage and their history to improve the distinctiveness of the Tlemcen city center. The distinctiveness value results from the Tlemcen city center's unique characteristics that make it special for local people and attract visitors searching for new experiences.

When it comes to the tourists' perceptions, the major part of them confirms the uniqueness of the city center environment. They were amazed by the city history and architecture and were mostly fascinated by the urban duality of this city center. The duality of the city's urban fabric and its aspects create a value of distinctiveness aspired and admired by the city center visitors.

\section{The Relation between the City's Two Parts: Distinctiveness Value}

The duality of the Tlemcen city urbanism creates a distinctiveness and uniqueness value of the city center urban form. Two urban fabrics coexist during the city center urban development. The first one is formal, implemented according to the prescriptions of the urbanism documents. The second one is informal, and it is the product of its builder's need for housing. This duality reveals the existence of two urbanisms but also two lifestyles. The first claims to encourage modernization; the other, by implementing the traditional constructive know-how, materializes the modes of autochthonous life.

The morphology of the city center urban fabric presents the contrast between the narrow, irregular paths of the old city and the geometrical layout of the colonial quarters. The first one grew naturally without any pre-established plan, while the second was built on a regular plan.

So, specific morphological characteristics are particular to each of the city center parts that derive their originality from the nature of the site, the techniques and materials used in the construction, and the lifestyle of inhabitants. All of that, taken together, constitute the uniqueness of the Tlemcen city center physiognomy; on the pre-colonial side, the homogeneous, agglomerated, dense, and introverted constructions of the Tlemcen Medina. On the other side, a more spacious and organized urban grid where a road network serves the European-style buildings.

\section{Tlemcen Colonial Heritage as a Resource}

According to our research findings, the Tlemcen city center's urban colonial heritage can be considered a resource that consists of the architecture and the urban planning ideas introduced by France in Tlemcen starting from 1842. The urban colonial heritage is now expressing how a nation has military and economically controlled another exogenous region. During the colonial presence time, the French authorities erected churches, administrative buildings, judicial and education buildings, defensive works, housings, prisons, roads and railways, manufacturing facilities etc. They enable them to control and manage the Tlemcen old city population and exploit their resources. 
Table 3. Informal talks' findings

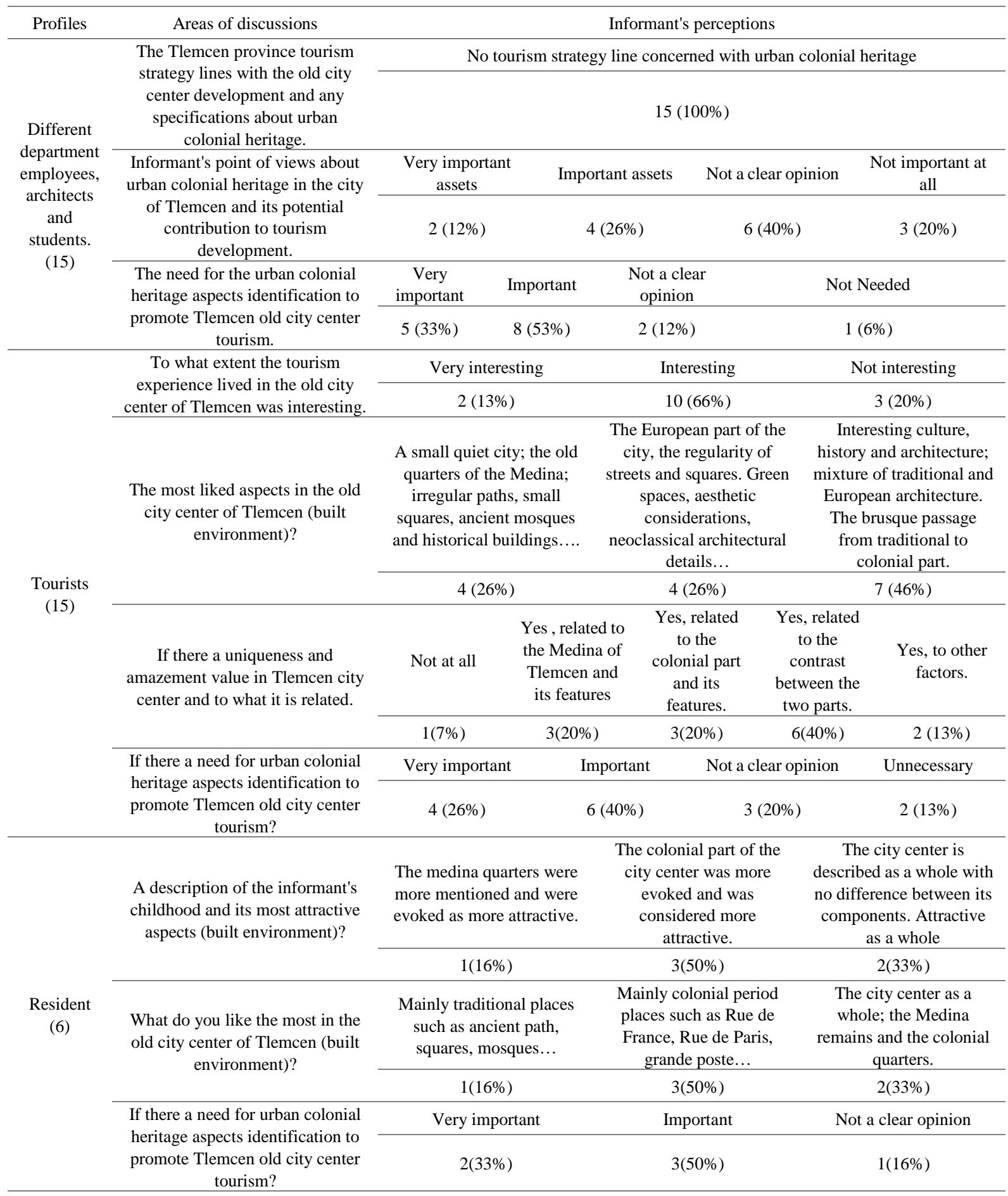




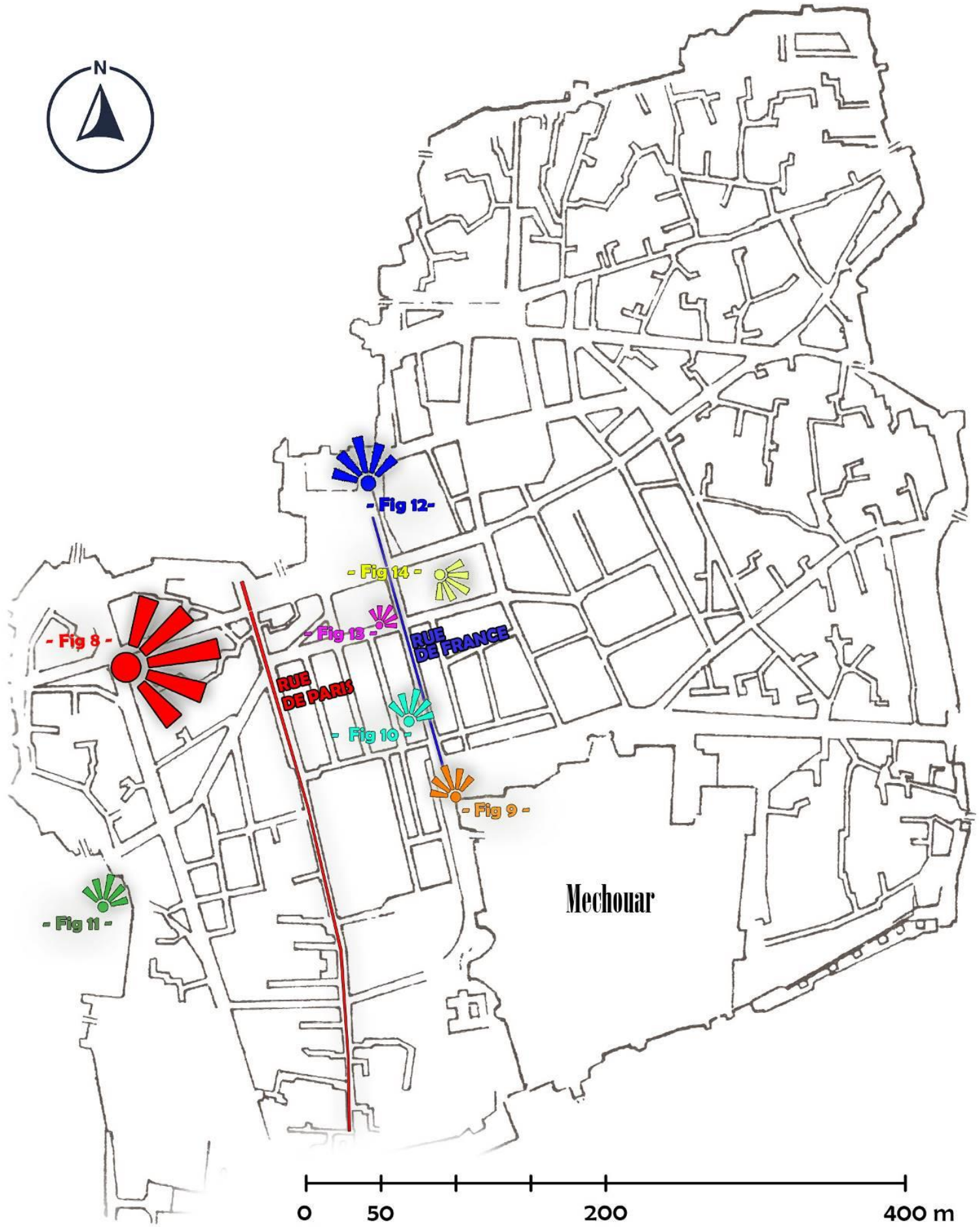

Figure 7. The points of view from which the photos (elements of design) were taken. Source: Authors

\section{Urban Colonial Heritage Aspects}

The urban colonial heritage of the Tlemcen city center's general features expressed the urban contrast with the preexisted indigenous settlement. Its general aspects can be summarized as follows:
- The colonial part of the city has overlapped a considerable part of the traditional preexisting settlement (Figure 4 and 6).

- The theoretical planning of the new colonial quarter was applied with no considerable modifications. This was in contrast with the traditional preexisting fabric 
in which the nature of the topography and the characteristics have largely influenced the settlements forms and development,

- The colonial architecture and urban planning were imported and extraverted, which was against the Medina of Tlemcen vernacular introverted buildings logic. However, it used local materials and construction techniques in the architectural expressions.

- The urban colonial heritage of the Tlemcen city center can present some local particularities due to tardive design ideas extended from local architecture traditions.

Documentary research and Discussions with the informants help the researchers identify more urban colonial heritage aspects and understand their historical value in Tlemcen city center.

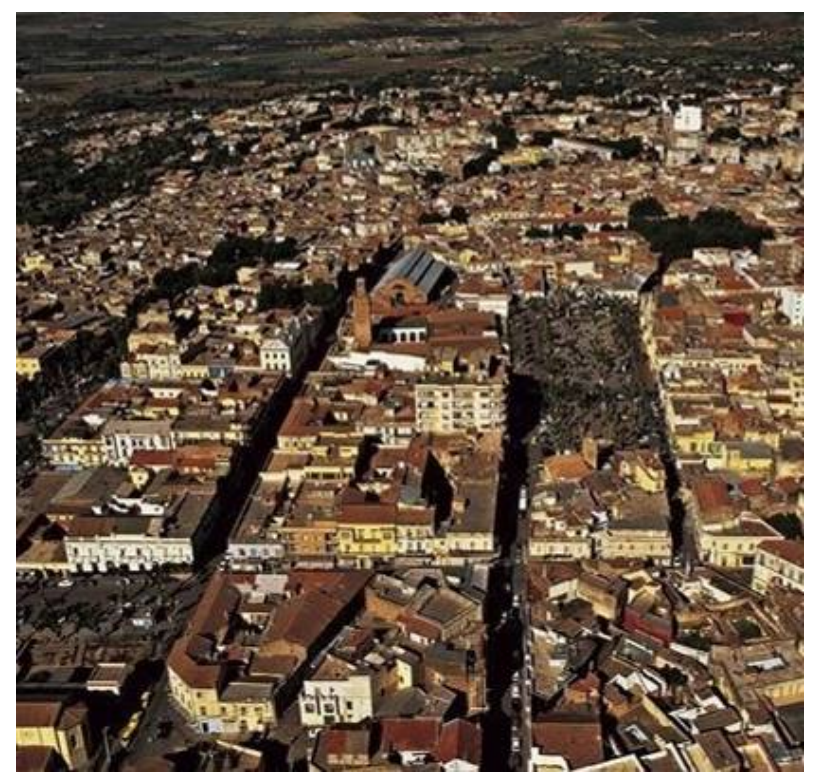

Figure 8. An aerial view of the Tlemcen old city showing the breakthrough roads (Date: 2004). Source: Yann Arthus BERTRAND [20]

\section{Breakthrough Roads}

According to the documentary research and informal talks' findings, the urbanism of the colonial occupation period in the old city of Tlemcen is not only based on aesthetic and hygienic principles as openly stated by the French armies but also based on ideological and military considerations; Because of its high-density occupancy and the complicated alleys network (Figure 8), the old Medina of Tlemcen inspires fear and mistrust in the military troops and is, therefore, necessary to open and allow the easy control of all places.

For that reason and starting from 1842, the piercing operations radically changed the configuration of the concentric traditional urban fabric and replaced it with a European quadrangular and regular urban fabric (Figure 4 and 6).
This operation also allowed the enlargement of existing alleys and the creation of broad roads that became essential for introducing new means of transport and establishing the urban façade, one of the significant components of the European urban landscape.

\section{Perspective View}

The urbanism of the French colonial period in the old city of Tlemcen was based on visual principles aimed at achieving an aesthetic quality of the urban landscape.

The perspective view (Figure 9) allows better visibility and ensures the contemplation of the various urban landscape elements and the valorization of the architectural details and the aesthetic qualities of constructions and monuments.

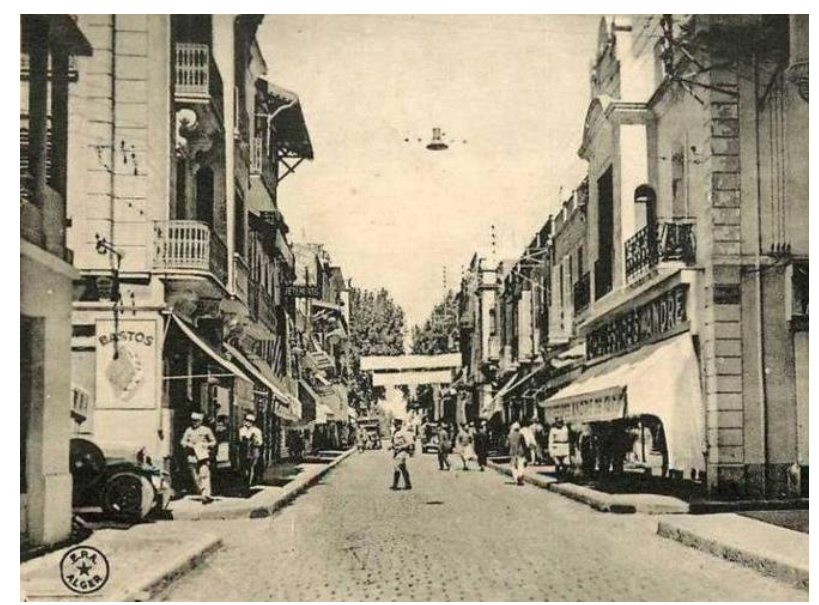

Figure 9. One of the perspective views offered in one of the Tlemcen streets (Rue de France) (Date: 1920). Source: Old postcard (African Photo Editions -Algiers)

Unlike the Tlemcen Medina with its blind walls, the perspective view encouraged the owners to enrich their building façades and their storefronts of which the openings were decorated with cornices that line up to form a perspective line just like in the case of the independence street that was known as Rue de France, which is one of the principals and wide breakthrough streets in which the buildings on both sides showed a rich decoration and reflect the importance given by the owners to decorative details.

\section{Street Alignment}

The street alignment was one of the required operations imposed by aesthetic (aesthetic rules framed the French colonial intervention; the Tlemcen medina have been the object of a regulation project which at the time was considered as a way to frame the aesthetic tastes and the way of life of the society) and hygienic reasons (The population rapid growth has put a great load on the medieval old cities' drinking water and sewage primitive facilities, which favored the apparition of epidemics such 
as cholera and typhus) and adapted with the new means of transport; to ensure the good functioning of the projected recent quarter. Thus, the mainstream solution for the French engineers was to keep the urban patterns as close as possible to a regular geometrical figure, and their preferred solution was a quadrilateral [17].

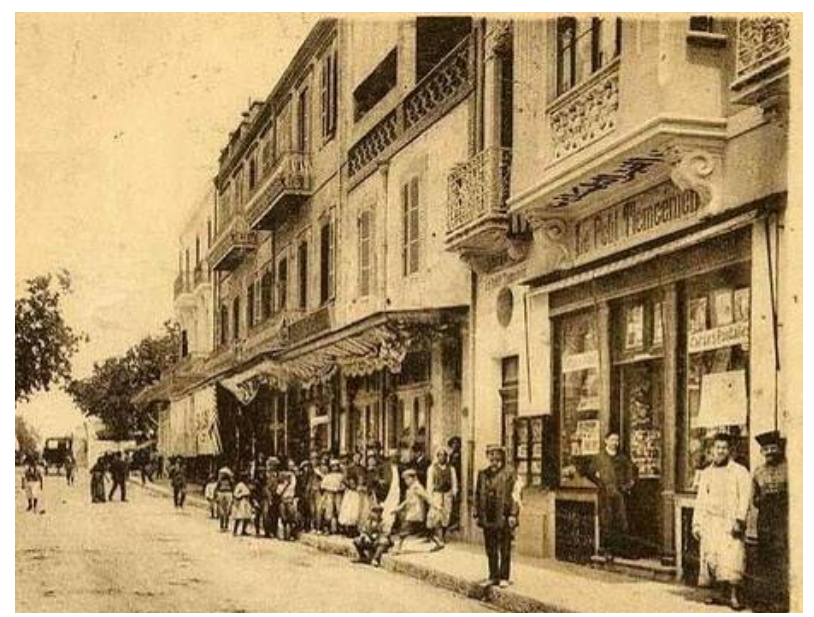

Figure 10. Constructions aligned according to the street limit (Date: 1928). Source: Old postcard (African Photo Editions -Algiers)

In other terms, the military authority in Tlemcen set a straight limit line on which any construction must be placed (Figure 10) and parallel to street lines which should also be parallel, taking Rue de France and Rue de Paris as an illustrative example.

\section{Commemorative Monuments}

The memorial monuments were attesting to the values of the French occupants during the colonial period; they contributed to the diffusion of the French occupant culture and consequently to the erasure of the indigenous one [21].

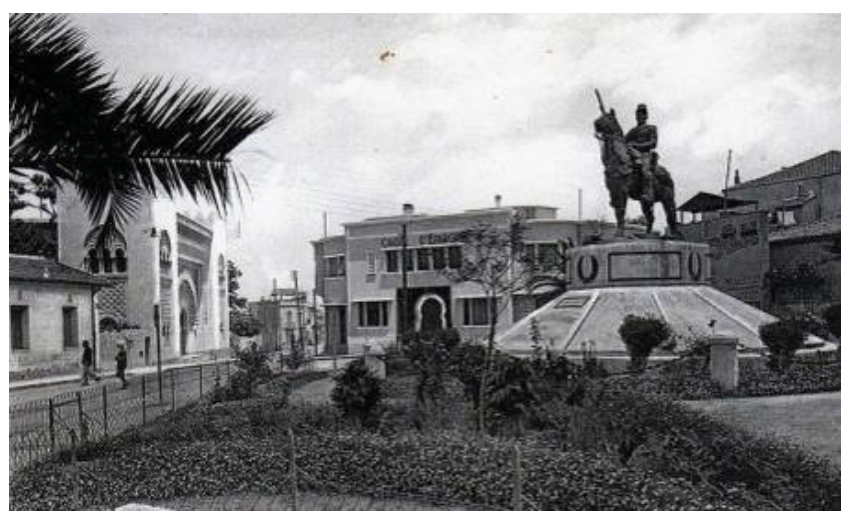

Figure 11. One of the Tlemcen Old City commemorative monuments established in front of the Tlemcen old French defense wall (Date: 1921). Source: Old postcard (African Photo Editions -Algiers)

The memorial monuments established during the colonial period in Tlemcen expressed the attachment of the French colonizers to the occupied land. They were dedicated to the glory of the French colonization and to reinforce French domination over the indigenous population and make the occupied city look more like the French homeland cities and towns (Figure 11).

\section{Urban Windows}

The urban project of the military genius in the Tlemcen old city during the colonial period was based on visual principles to take into account the aesthetic potentialities of the natural and the urban landscape. The urban fabric introduced during this period had reserved several urban openings orientated towards interesting natural views (Figure 12) or squares and monuments.

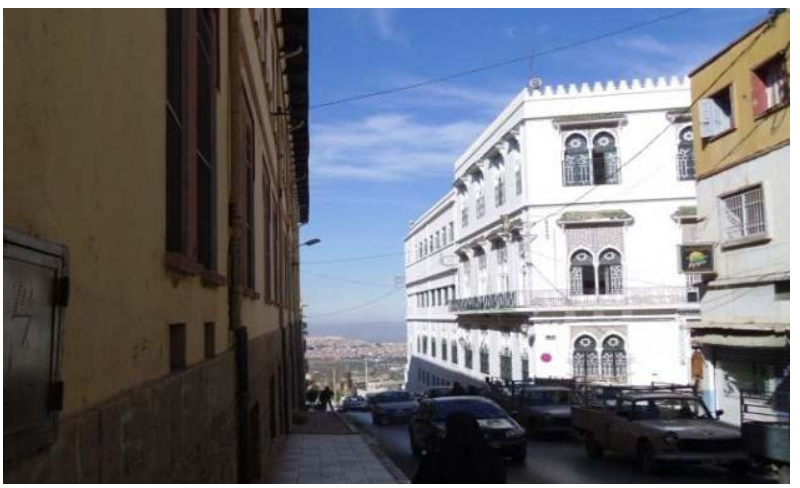

Figure 12. One of the urban windows orientated towards the north side (Date: 2019). Source: Author

\section{Public Places}

At first, public places were established to gather the troops and to organize the parades, but over time, those spaces had been loaded with exceptional and symbolic value and filled with emotional aspects (Figure 13); they translated the public authority and served as a support for commemorative and colonial events. The public squares had been treated with special attention; they were provided with pavements, freshwater, plants, and street furnishings [17].

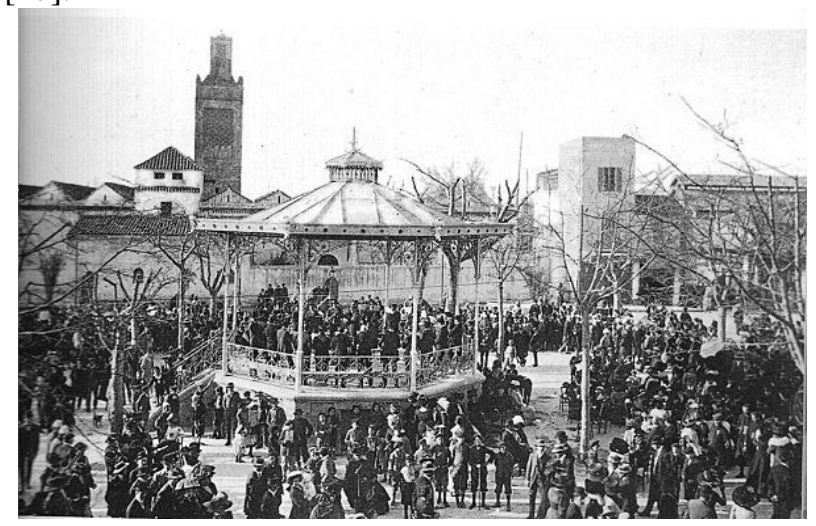

Figure 13. The main and the most important place in the old city of Tlemcen (Date: 1921). Source: Old postcard (African Photo Editions -Algiers)

Equity in distributions of urban public infrastructure is 
the dominant objective for regenerating public urban spaces by referring to people [23].

\section{Official Buildings}

The official buildings constructed during the colonial period in Tlemcen were structural elements of the introduced urbanism of this period; their presence gave importance to the place and drained public influence.

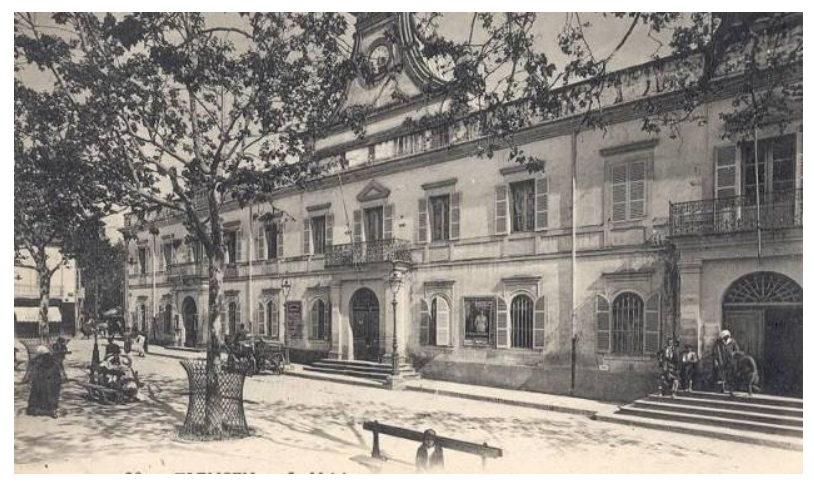

Figure 14. One of the important official buildings in the French occupation period in the old city of Tlemcen (Date: 1921). Source: Old postcard (African Photo Editions -Algiers)

Most of these buildings were constructed with neoclassical architecture style (Figure 14) and distinguished by their regular shape plan, symmetric elevations, and homogeneous geometric order.

\section{Conclusions}

Tlemcen was one of the Arab-Muslim old cities partially remodeled according to the French ideology of direct rule that justified colonialism as a civilizing project to modernize and transform the colonial territories [22]. In this context and from 1842, this ideology had led to a series of radical transformations that radically changed the spatial and morphological structure (radio-centric) of the Tlemcen Medina; The regularization projects of the existing Medina gave rise to relatively new urbanism that is in complete contrast with the pre-colonial vernacular one which reflected the values and the principles of the traditional local knowledge.

As the traditional urban fabrics of the Medina, the French urbanism introduced between 1842 and 1902 is nowadays seen as a significant part of the urban cultural landscape of the Tlemcen city center and is considered to have important heritage values, therefore, touristic potentialities.

Until the present time, too few works have focused on the cultural importance of the urban colonial heritage and its aspects and significance as a key component in a potential sustainable tourism strategy. In this respect and through this article, we intend to raise the awareness and the appreciation of these urban colonial heritage aspects in the Tlemcen city center and the importance of their identification for the enhancement of tourism.

According to this research approach, the article has identified and brought out the main aspects of the colonial urban planning characterizing the long period of colonial presence in Tlemcen, which are considered to have aesthetical and testimonial values and can therefore be seen as an asset for the tourism enhancement in the case of the old city of Tlemcen.

The reconnaissance work has underlined the aesthetical quality of the colonial introduced urbanism based on visual principles such as perspective views reinforced with a neoclassical architecture and urban windows orientated towards the surrounding environment and public places finely made. This work has also identified elements with a testimonial value, such as commemorative monuments and breakthrough roads, which express the so-called French culture supremacy over the native one; Colonial urbanism functioned as a means of and a reason for social control and segregation.

Colonial urbanism and architecture heritage values are thus confirmed through the presented aspects. It is, therefore, necessary to raise public awareness to develop them as tourism attractions.

\section{REFERENCES}

[1] M. Larnaude, "Houses and their grouping, in relation to the way of life, of the Algerian Tel natives," Bulletin de l'Association de Géographes Français, vol.21, no.159, pp.31-40, 1944. https://doi.org/10.3406/bagf.1944.7638.

[2] A. Picard, "Architecture et urbanisme en Algérie. D'une rive à l'autre (1830-1962)," Revue des mondes musulmans et de la Méditerranée, vol.73, no.1, pp. 121-136, 1994. https://doi.org/10.3406/remmm.1994.1671.

[3] O. White, "Great Men in Greater France: Léon Poirier's L'Appel du silence and Brazza, ou l'épopée du Congo," French Colonial History, vol.18, pp. 129-154. 2019. https://doi.org/10.14321/frencolohist.18.2019.0129.

[4] G. Wright, "Tradition in the service of modernity: architecture and urbanism in French colonial policy, 1900-1930," The Journal of Modern History, vol.59, no.2, pp. 291-316, 1987. https://doi.org/10.1086/243186.

[5] L. Abadie, Tlemcen au passé retrouvé. Nice: Editions Jacques Gandini, 1994.

[6] R. I. Lawless, "Mauretania Caesartiensis: an archaeological and geographical survey," Ph.D Dissertation, Durham University, 1969.

[7] A. N. Sherwin-White, "Geographical Factors in Roman Algeria,"The Journal of Roman Studies," vol.34, no.1-2, pp. 1-10, 1944. https://doi.org/10.2307/296776.

[8] M. MacCarthy,"ALGERIA ROMANA Subdivision de 
Tlemsên" Revue Africaine, vol.1, pp.94, 1856.

[9] G. Marçais, Tlemcen: les villes d'art célèbres. Paris: H. LAURENS, 1950.

[10] M. Garcia-Arenal and E. Manzano, "Idrissisme et villes idrissides," Studia Islamica," vol.82, pp.5-33, 1995. https://doi.org/10.2307/1595579.

[11] H. Ilahiane, Historical dictionary of the Berbers (Imazighen). Washington DC: Rowman \& Littlefield, 2017.

[12] C. Robinson, "Power, Light, Intra-Confessional Discontent, and the Almoravids," Envisioning Islamic Art and Architecture: Essays in Honor of Renata Holod, p.22, 2014. https://doi.org/10.1163/9789004280281_003.

[13] B. Hassar, "Aperçu historique: Tlemcen, ancienne capitale do Maghreb central," Le lien bulletin de l'association les amis de Tlemcen, vol. 1, pp.5-6, 2000.

[14] R. I. Lawless, "Tlemcen, capital of the central Maghreb. Function analysis of an Islamic medieval city," Revue de l'Occident musulman et de la Méditerranée, no.20, pp. 49-66, 1975. https://doi.org/10.3406/remmm.1975.1329.

[15] X. Malverti and A. Picard, "Algeria: Military genius and civic design (1830-70)," Planning Perspective, vol.6, no.2, pp. 207-234, 1991.https://doi.org/10.1080/02665439108725 727.

[16]A. Charpentier, "D’un urbanisme médiéval vers un urbanisme européen: l'exemple de Tlemcen". In Formes urbaines et architectures au Maghreb aux 19e et 20e siècles,
L. Amar, Ed. Paris: Centre de publications universitaires, pp. 55-66, 2011.https://hal.archives-ouvertes.fr/hal-01994521/d ocument.

[17] P. Moncan and C. Marville, Paris avant-après Haussmann. Paris: Les éditions du mécène, 2012.

[18] R. Gutiérrez, "Buenos Aires, A Great European City," in Planning Latin America's Capital Cities 1850-1950, A Almandoz, ed., New York: Routledge, 2002, pp. 45-74.

[19] D. P. Jordan, "Haussmann and Haussmannisation: the legacy for Paris," French Historical Studies, vol.27, no.1, pp. 87-113, 2002. https://doi.org/10.1215/00161071-27-1-87.

[20] Y. A. Bertrand, www.yannarthusbertrand2.org (retrieved Jan, $6,2020)$.

[21] Z. Çelik, Z. "Colonial/Postcolonial Intersections: 'Lieux De Mémoire’ in Algiers. "Historical Reflections, vol.28, no.2, pp. 143-162, 2002. https://doi.org/10.1080/0952882990857 6823.

[22] A. Lawrence, "Colonial approaches to governance in the periphery: Direct and indirect rule in French Algeria," in Colonial encounters and divergent development trajectories in the Mediterranean, Cambridge, December 1, 2016. Cambridge, MA: Harvard University.

[23] R. Rahbarianyazd, "Regeneration as a Tool for Enhancing Vitality of Urban Spaces" Civil Engineering and Architecture, vol. 8(5), pp. 908-915. https://doi.org/10.13189/cea.2020.080518. 